\title{
EXPLAINING MIXED RESULTS ON SCIENCE PARKS PERFORMANCE: BRIGHT AND DARK SIDES OF THE EFFECTS OF INTER-ORGANISATIONAL KNOWLEDGE TRANSFER RELATIONSHIPS
}

\author{
K.Y.A. Chan ${ }^{1 *}$, L.A.G. Oerlemans ${ }^{1,2}$ and M.W. Pretorius ${ }^{1}$ \\ ${ }^{1}$ Graduate School of Technology Management \\ University of Pretoria, South Africa \\ alice.chan@up.ac.za, tinus.pretorius@up.ac.za \\ ${ }^{2}$ Department of Organisation Studies \& Center for Innovation Research \\ Tilburg University, The Netherlands \\ L.A.G.Oerlemans@uvt.nl
}

\begin{abstract}
In the recent past, several researchers explored the added-values of Science Parks. On the basis of empirical research, some questioned the assumed benefits of the science park model, whereas others reported positive outcomes. As a result, mixed findings regarding the benefits of science parks for firms can be observed. These mixed empirical findings require a theoretical explanation. This paper argues that different levels and types of knowledge exchange behaviour of science park firms could be one of the theoretical explanations for these mixed findings. The literature on networks mainly stresses the benefits of networking in general, and networking between firms located on science parks in particular. This paper proposes that networks can have both positive (knowledge sharing) and negative effects (opportunistic behavior and knowledge spillovers) for firms located on science parks. When the latter occurs, location on a science park might produce negative effects. A conceptual model is developed that summarises our theoretical arguments.
\end{abstract}

\section{OPSOMMING}

Verskeie navorsers het in die onlangse verlede die waardetoevoeging van Wetenskapparke ondersoek. Empiriese navorsingsresultate dui enersyds daarop dat die voordele van Wetenskapparke bevraagteken moet word, maar andersyds dat daar positiewe uitkomste ook is. Dit is dus nodig dat hierdie teenstrydige resultate verder ondersoek en teoretiese verklarings daarvoor gevind moet word. In hierdie artikel word geargumenteer dat verskillende vlakke en tipes kennisuitruil gedragspatrone van firmas wat in Wetenskapparke gestasioneer is, een van die teoretiese verklarings vir bogenoemde teenstrydige bevindings is. Die algemene literatuur oor netwerke lê hoofsaaklik klem op die algemene voordele van netwerking tussen firmas binne Wetenskapparke. Hierdie artikel argumenteer dat netwerke beide positiewe (kennisdeling) en negatiewe (opportunistiese gedrag en kennisoorspoeling) effekte vir firmas binne Wetenskapparke kan inhou.

\footnotetext{
${ }^{1 *}$ The author was enrolled enrolled for a PhD (Technology Management) degree in the Graduate School of Technology Management, University of Pretoria.
} 


\section{INTRODUCTION}

The majority of the world's science parks were created during the 1990s, but about $18 \%$ of those now in existence were launched in the first two years of the third millennium [12]. This rapid growth of science parks has attracted the interest of many reseachers $[1,2,3,4$, $5]$. In the recent past, several researchers explored the added-values of science parks $[4,6$, 7] by exploring the characteristics and performance of firms located on and outside science parks. They showed that science parks provide an important resource network for on-park new technology-based firms (NTBFs), and that on-park NTBFs are likely to establish knowledge linkages.

However, other researchers questioned the assumed benefits of the science park model [8, $9,10]$, finding that firms did not gain any benefits from networking and clustering or from the linkages between academic research and industrial activity. How can these different empirical findings be explained from a theoretical point of view? This paper tries to answer this main research question, and proposes that knowledge flows in networks can have both positive and negative effects for firms located on them. It distinguishes two kinds of knowledge flow amongst organisations: 'intended' and 'unintended'. The effects of both are combined with geographical and technological proximity. Two contrasting views can be derived from the literature about the effects of this specific combination. Alcacer and Shao found that firms try to prevent the risk of unintended knowledge outflow by locating themselves further away from competitors with similar technological backgrounds and in similar industries [11]. This implies that clustering firms together (as on a science park) increases the likelihood of unintended knowledge flow, and thus firms with leading technologies will, if possible, move away further from their competitors to prevent their technology spilling over to them. On the other hand, the main purpose of science park location is to aggregate firms in related industries and supporting organisations (i.e., to create high geographical proximity), so that they are able to collaborate in research, thus facilitating intended knowledge exchanges. These contrasting views create a gap in the literature and lead to the main hypothesis of this paper: The positive relationship between intended knowledge flows and innovative performance of firms will be negatively moderated by higher levels of unintended knowledge flow. This moderating effect is stronger for on-park firms than for off-park firms. To formulate an answer to the main research question, the following research subquestions are formulated:

- What are the effects of intended inter-organisational knowledge transfer on the innovative performance of firms located on and off science parks?

- What are the effects of unintended inter-organisational knowledge flow (knowledge spillover) on the innovative performance of firms located on and off science parks?

The aim of this study is to reconcile theoretically the mixed results found in empirical research on science park performance. Moreover, it proposes a research model with which the propositions developed in this paper can be tested empirically. The remainder of this paper is structured as follows. Section 2 gives a brief background to the development of science parks around the world and to the characteristics that form the focus of this study. Section 3 investigates the literature of networks and knowledge flows with respect to innovations. Several propositions are formed to build the theoretical model of this study. Section 4 concludes the paper.

\section{SCIENCE PARKS: HISTORY OF DEVELOPMENT, DEFINITION, AND CHARACTERISTICS}

\subsection{History of development of science parks}

Science parks are not a new phenomenon. The first science-based park, Stanford Industrial Park (later leading to the development of Silicon Valley), was established in Palo Alto in the USA in 1951. Cambridge Science Park was established in the UK in 1972. The Association of University Research Parks (AURP) reports that there are now 123 university-based science parks in the United States [13]. The UK Science Park Association (UKSPA) has reported that 
there were 32 science parks in the UK in 1989, and 46 in 1999. There are more than 200 science parks in Asia, with Japan topping the list with 111 initiatives. There are now more than 400 science parks worldwide, and the number continues to grow rapidly due to regionally targeted initiatives introduced by governments and other organisations to provide an appropriate physical infrastructure for a successful local economy and social environment [14].

\subsection{Definitions of science parks}

In 1986 the UKSPA defined a 'science park' as a property-based initiative that:

- has formal operational links with a university or other higher educational or research institution,

- $\quad$ is designed to encourage the formation and growth of knowledge-based businesses and other organisations normally resident on-site,

- has a management function that is actively engaged in the transfer of technology and business skills to the on-site organisations.

In 1998, another science park association, The Association of University Related Research Parks (AURRP), stated in its Worldwide Research \& Science Park Directory:

"The definition of a research or science park differs almost as widely as the individual parks themselves. However, the research and science park concept generally includes three components:

- A real estate development

- An organizational program of activities for technology transfer

- A partnership between academic institutions, government and the private sector."

A more recent visit to the website of the International Association of Science Parks (IASP) [12] reveals their official definition of a science park:

"A Science Park is an organisation managed by specialised professionals, whose main aim is to increase the wealth of its community by promoting the culture of innovation and the competitiveness of its associated businesses and knowledgebased institutions. To enable these goals to be met, a Science Park stimulates and manages the flow of knowledge and technology amongst universities, R\&D institutions, companies and markets; it facilitates the creation and growth of innovation-based companies through incubation and spin-off processes; and provides other value-added services together with high quality space and facilities."

Even though there are several definitions and an absence of a generally accepted definition for the term science park, these definitions outline the important aspects of a science park, such as links with universities, a management function, a knowledge-sharing environment to encourage innovations, and the creation of spin-off companies. This paper uses the IASP's definition, as it includes most of the aspects of a science park.

\subsection{Characteristics of science parks}

The subject of science parks has generated a vast amount of literature, with various aspects of science parks' characteristics being researched. These characteristics include:

\section{Clustering}

High tech firms with similar characteristics (e.g. sharing a common market for their end products, using a similar technology or labor force skills, or requiring similar natural resources) and/or within the same value chain (i.e. linked by buyer-seller relationships) 
would be attracted to cluster together as a strongly allied group to complement each other [8]. This phenomenon can be seen in science parks that are supposed to be a geographically concentrated cluster of independent firms that are technology-related and knowledgebased, and supported by other organisations. Through this clustering, firms have a degree of 'geographical proximity' that facilitates knowledge flows. Studies have shown that the maximum flow of information and ideas exists amongst geographically proximate firms [15] because this supports the learning process through networking, and thus positively influences the innovative outputs of firms [16].

\section{Academic-industry link}

The transformation of scienctific knowledge into technological innovation lies at the core of science parks $[9,17]$; thus a host academic institution, usually an Higher Education Institute $(\mathrm{HEI})$, is often formally associated with a park. This academic-industry link can take many forms $[9,18]$ :

- The transfer of people, including founder-members of firms, key personnel, and staff into employment in firms;

- The transfer of knowledge through collaboration with researchers and students of HEls;

- Contract development, design, analysis, testing, evaluation, etc.;

- Access to university facilities;

- The establishment of 'academic spin-off firms', formed by academic staff taking research out of the laboratory and into the science park, starting their own commercial enterprise.

The presence of HEls often improves the prestige or image of science parks, and is often a major factor in a firm's decision to locate on a science park $[18,19]$. The contribution of HEls has set the science park apart from other property initiatives, and also helps to raise rental values.

\section{Management function}

From the UKSPA's definition of a science park, it follows that it has a management function that is actively engaged in facilitating the transfer of technology and business skills to the organisations on site. Johannisson [20] has explained a science park's management function as a formal administrative structure to manage the property on the park and/or to manage the delivery of auxiliary activities and professional services required by firms located on science parks, with a focus on channelling information and resources to the on-park firms [5] by providing networking services, both internal (among on-park firms and HEls) and external (with customers, collaborators, and potential investors) [21]. A managed science park will have a general full-time manager or management company on-site whose principal task is to manage the park. Westhead and Batstone have pointed out that science parks generally need to strengthen their managerial functions, with an emphasis on developing an effective way to link tenant firms to the facilities and resources provided by a local HEI [5].

\section{Knowledge flows}

Firms located on science parks are bound in space, and are therefore geographically closer to each other than rival firms located elsewhere. This spatial agglomeration promotes the transmission of knowledge due to the lower costs of communication in a dense environment. Researchers have distinguished two categories of knowledge transmission: intended and unintended knowledge flows [22, 23]. If knowledge is exchanged with the intended people or organisations, it is 'knowledge transfer'; any knowledge that is exchanged unwillingly and outside the intended boundary is 'knowledge spillover'. When firms form networks (formally via collaboration, or informally via social networking) in science parks, knowledge exchange occurs via these direct connections [24, 25]. Economists have been studying 'knowledge spillovers', as firms investing in research and development end up facilitating other firms' innovations by revealing their knowledge unintentionally 
[26, 27]. A firm can access unintended knowledge in various ways, such as knowledge from reverse engineering on rivals' innovative products, or knowledge from patent information.

These science park characteristics enable us to build our theoretical framework in the following section.

\section{THEORETICAL FRAMEWORK AND CONCEPTUAL MODEL}

\subsection{Knowledge transfer networks}

There is a common emphasis in the literature on the importance of inter-organisational networks and networking for innovation through the external acquisition of knowledge and information $[28,29,30]$. Many aspects of networks are studied in the literature, but for the purpose of this paper, the emphasis is on pursuing networking to profit from intended knowledge flows. Two levels of analysis can be seen in network studies: whole networks, and egocentric networks. At the whole network level, the entire set of present and absent linkages amongst firms needs to be examined. For this paper, it is assumed that the boundary of the network of science park firms is difficult to determine: on-park firms can also have many links with firms off-park, and the network structure of this latter group of firms is hard to determine. Therefore the so-called egocentric network level is chosen for this study, as it considers only the direct linkages ('alters') of a given (science park) firm ('ego'), and from an operational perspective this usually relies entirely on 'ego's' selfreports about its network. To build our argument we use three concepts: degree centrality, tie characteristics (trust, proximities, and knowledge quality), and diversity of actors, and relate these to knowledge transfer and innovation.

\section{Number of inter-organisational knowledge transfer relationships and innovation}

During the 1990s, innovation accelerated and increasingly involved interorganisational networking [31]. Through networking, firms are able to access knowledge externally from other actors and develop their own innovations. When firms interact formally (by explicit agreement) or informally (on a social basis), knowledge sharing often occurs, and the resultant knowledge is available to partners. Evidence from the literature shows that "those firms which do not co-operate and which do not formally or informally exchange knowledge, limit their knowledge base over the long term and ultimately reduce their ability to enter into exchange relationships" [30]. Network position, such as centrality, is an important aspect of the network structure because it conditions the degree to which an actor has access to resources throughout the network. Centrality (as a type of network position) indicates the involvement of an actor in the network; the more a firm is involved in its network, the more it can compare information across multiple information sources and discover new information. More central firms are less likely to miss any vital information, and are able to combine information in novel ways to generate innovations [32]. Various studies have shown that centrality is strongly associated with innovation and enhances firm performance [33, 34, 35]. This leads to our first proposition:

Proposition 1: The more direct ties that a firm maintains, the higher the firm's innovative performance.

While most researchers pay attention to network structures [36, 37, 38, 39], others have argued that the characteristics of ties within networks cannot be neglected as they also influence the performance of actors [24, 40, 41]. Ties are connections between nodes. In this case the nodes are organisations, and the connection is the interactions between them that make knowledge transfer possible. As mentioned earlier, some researchers have focused more on the dynamics of ties/ relations rather than their structural configuration. Various aspects of ties dynamics can be considered, such as purpose, direction, content, and strength [42]. This study focuses on knowledge as the tie content, and thus the purpose of a tie is knowledge-sharing for innovation. The other two dynamics of ties - strength (associated with trust and proximity) and content (quality of knowledge flowing in the tie) need to be explored to understand fully the characteristics of a tie. 
The willingness of organisations to exchange knowledge and information is often associated with tie strength [43, 44], and studies have identified trust between partners in interorganisational relationships as an important relational asset [45] that promotes willingness to exchange knowledge. Trust can be defined as "the judgment one makes on the basis of one's past interactions with others that they will seek to act in ways that favour one's interests, rather than harm them" [46]. From this definition, trust can minimise risks that stem from exposure to opportunistic behaviour by partners. Through past interactions, organisational members are more emotionally involved, and eventually trust is built between them. This is often called the 'intentions' form of trust [47] because this refers to the belief that partners intend to uphold the commitments they make. Another form of trust is 'competence-based trust', which refers to the belief the partners have in their capabilities to meet joint commitments. In this study, 'trust' refers to the belief that a partner is capable (= competence) to provide the knowledge a firm needs for innovation, and to the belief that partners are willing to share such knowledge for the benefit of each other (= intentions). Therefore, the higher these trust levels, the more willing actors are to exchange knowledge and information. As a result of this exchange, actors can increase their innovative performance. Based on the above discussion, the following hypothesis is developed:

Proposition 2: The higher the level of trust a firm has with its actors, the higher the firm's innovative performance.

\section{Proximities, inter-organisational knowledge transfer, and innovation}

Gertler states that "recent work on innovation and technology implementation suggests the importance of closeness between collaborating parties for the successful development and adoption of new technologies" [48]. In the literature, this closeness between organisational actors is also known as the 'proximity' concept - "being close to something measured on a certain dimension" [49]. Scholars distinguish various dimensions of proximity, and most of the time their definitions overlap. Following Knoben and Oerlemans' literature review, this paper uses three dimensions of proximity, and relates these to knowledge transfer and innovation.

In the study of innovation and knowledge transfer, there is an emphasis on the importance of geographical proximity for the transfer of (tacit) knowledge. The concept is often defined as geographical distance expressed as a specified radius of each firm [50], or as travel times/ perception of this distance [51]. A short distance between two actors facilitates knowledge-sharing and in particular the transfer of tacit knowledge. Tacit knowledge transfer is enhanced through face-to-face contacts, and so the spatial dimension is essential. However, the concept of proximity goes beyond geographical distance. Technological proximity refers to the similarities between actors' technological knowledge - in other words, how the knowledge exchanged between them is related. Transferring unrelated knowledge can cause difficuties in assimilation and application of the knowledge [52] because the firm that receives the knowledge is not able to identify, assimilate, or exploit knowledge coming from external sources ('relative absorptive capacity' as defined by Lane and Lubatkin [53]). The third dimension of proximity is organisational proximity. In Knoben and Oerlemans' paper (based on Rallet and Torre [54]), organisational proximity is defined as "the set of routines - explicit or implicit - which allows coordination without having to define beforehand how to do so. The set of routines incorporates organizational structure, organizational culture, performance measurements systems, language and so on". Collaborating firms that have low organisational proximity have different sets of routines, and thus instead of creating innovations together, these non-overlapping routines create problems; and in a worst case scenario, unsuccessful collaboration produces no innovative outputs. Based on the discussion above, geographical, technological, and organisational proximity between firms enhances the ease with which 
firms collaborate in general, and exchange knowledge in particular. Consequently, firms can increase their innovation outcomes. Hence:

Proposition 3: The more innovating firms are proximate (geographically, technologically, organisationally) to their partners, the higher their innovative performance will be.

\section{Qualities of knowledge exchanged and innovation}

Soo and Devinney's paper found a positive relationship between knowledge quality and innovative performance [55]. The quality of knowledge exchanged comprises two factors: usefulness of the knowledge that a firm receives for its innovation, and how frequently it receives the knowledge. The context of the knowledge that a firm receives directly influences the success of the innovative outcomes if the firm can actually use such knowledge. The knowledge can be new to the receiving firm, but if it cannot be used and contribute to the firm's development of new innovation, then such knowledge has low knowledge quality to the firm. The frequency of receiving knowledge (knowledge transfer) also is a dimension of the quality of the knowledge, because more frequent communication can lead to more effective communication [56]. With frequent communication the receiving firm can better understand the knowledge that it receives and increase the chances that the knowledge is useful for the firm's innovation. Audretsch and Feldman also mention in their 2004 study that the marginal cost of transmitting knowledge, especially tacit knowledge, is lowest with frequent social interaction, observation, and communication [57]. This leads to our fourth proposition:

Proposition 4: The higher the usability of the acquired knowledge and the higher the communication frequency, the higher the innovative performance of firms.

\section{Diversity of network actors}

Many innovators derive their ideas from a diverse set of actors, because these provide diverse and non-redundant ideas that are a source of novelty, which can trigger new ideas and creativity in the knowledge-acquiring firm. Those who interact with partners from diverse communities of practice will be able to convey more complex ideas than those individuals who are limited to interactions within a single body of knowledge [56]. Diversity of actors in a network is important to innovation because it is not only the size of the network that maximises information, but also those actors found in networks composed of firms with different but complementary knowledge [58, 59, 60]. Knowledge-building and innovation often requires dissimilar, complementary bodies of knowledge from diverse actors [61]. Diversity is defined here as "multiple sources of knowledge such as competitors, customers, suppliers, HEl, etc. that a firm has". The relationship between diversity and innovation is formulated as follows:

Proposition 5: The higher the diversity of actors that a firm has in its ego-network, the higher its innovative performance.

The propositions developed so far stress the positive sides of inter-organisational knowledge exchange relationships and networks for innovating firms in general, and for firms located on science parks in particular. Inter-organisational networks give innovating firms the possibility to mobilise, coordinate, and combine knowledge resources. Provided that firms have the ability to process the acquired knowledge (see the next section on absorptive capacity), (geographically clustered) networks are argued to be beneficial to innovating firms. Moreover, it is assumed that the transfer of knowledge is intentional.

From the above arguments, the lower levels of success in science parks and of the firms located there can be simply explained by, for example, the absence of direct ties, levels of trust that are too low, or levels of diversity that are also too low. It is our argument that such explanations are too simple, and that other mechanisms are at work. These mechanisms imply the combined effects of high levels of technological and geographical 
proximity, as is often the case between firms located on science parks; the fact that knowledge transfer can be unintentional; and the characteristics of knowledge. To start with the last factor: one can argue that knowledge has two basic characteristics that make this 'commodity' look to some extent like a public good: rivalry and appropriability. Rivalry refers to the fact the use of a good by an actor does not affect the utility of other actors using the same good. Appropriability refers to the extent to which it is possible to exclude actors from using a good. A purely private good has high levels of rivalry and appropriability, whereas the opposite is true for so-called public goods. It often is argued that knowledge is a pure public good, but we argue that this point of view cannot be sustained. After all, the more actors use knowledge generated by another actor, the higher the probability that the economic value of it decreases over time as more actors get to know it. As a result the competitive advantage that firms can derive from this knowledge diminishes. In other words, rivalry is not complete. The same is true for appropriability: depending on the type of knowledge, other actors can be excluded, which is especially true for more tacit types of knowledge.

It was stated above that many studies on inter-organisational networks and science parks assume that knowledge sharing is intentional: a sender deliberately and consciously transmits knowledge to one or more recipients. However, knowledge can also be transferred unintentionally or in unintended ways through direct communication (e.g. observation of another actor's actions) or indirect communication (e.g. through (illegal) use of media on which knowledge or information is stored).

A third element in our theoretical argument is access conditions - the conditions under which exclusion cannot be accomplished. It is maintained that locations such as science parks create access conditions that benefit the unintended flow of knowledge. Geographical co-location on a science park makes it easier to observe the activities of other science park firms. Moreover, on average these research-intensive firms are technologically close, which also allows unintended flows of knowledge.

When combined, our arguments lead to the conclusion that science parks can 'facilitate' unintended knowledge flows. As explained in the next section, this can have both positive and negative effects for science park firms and for the networking function of science parks.

\subsection{Unintended knowledge flows (knowledge spillover)}

Researchers $[22,23,62,63]$ relate unintended knowledge flows to the knowledge spillover literature. They define 'unintended knowledge flow' as the transmission of knowledge to other actors on an involuntary and unintended basis - in other words, unintentional transmission of knowledge to others beyond the intended boundary. This type of knowledge flow can be acquired without the knowledge of the sending firms, and often zero or low costs are involved. In various knowledge spillover studies, researchers attribute positive innovation effects to knowledge spillovers [22, 23, 64]. Therefore we offer proposition 6.

Proposition 6: Higher levels of unintended knowledge flows will result in higher firm innovative performance.

Moreover, we propose that the relationship between intended knowledge flows (intentional knowledge transfer) and innovative outcomes of science park firms will be negatively influenced by higher levels of unintended knowledge flows, because the moment that the sender-firm realises that its knowledge is being 'used' without its approval by the receiving-firms, this will lower their willingness to share knowledge in official collaborations and/or informal networking activities. Hence:

Proposition 7: The relationship between intended knowledge flows and innovative performance of firms will be negatively moderated by higher levels of unintended knowledge flows/spillovers. 
In other words, if the unintentional use of knowledge is discovered by the knowledgeproducing science park firm, it will damage trust and thus lower the willingness to exchange knowledge. Again, technological and geographical proximity play their role, because they make it easier to observe a misuse, whereas network ties among firms on a science park make it easier to communicate the 'misbehavior' of an organisation. The more firms behave in this opportunistic way, the higher the probability that network processes on a science park will be inhibited. In fact, the poor performance of some science parks reported in the literature could be explained by the accumulated negative effects of the use of unintended knowledge transfer.

\subsection{Absorptive capacity}

In Cohen and Levinthal's 1990 study, firms' fundamental learning processes - that is, their ability to identify, assimilate, and exploit knowledge from the environment - are labeled 'absorptive capacity' [65]. Sahra and George later proposed additional definitions that separate Cohen and Levinthal's definition of absorptive capacity into two main dimensions: potential absorptive capacity (the capability to acquire and assimilate knowledge) and realised absorptive capacity (the exploitation or use of the knowledge that has been absorbed) [66]. Many empirical studies have shown that there is a positive relationship between absorptive capacity and innovation. Pennings and Harianto's study showed that prior accumulated experience in a certain technological area increased the likelihood of innovation adoption [67]. Becker and Peters [68] and Nelson and Wolff [68] argue that firms need higher absorptive capacities for scientific knowledge than for other types of knowledge. This shows that absorptive capacity is essential for the use of scientific knowledge that in turn is the basis of radical innovation. Hence:

Proposition 8: Higher levels of absorptive capacity will result in higher firm innovative performance.

Networking encourages the sharing of tacit and explicit knowledge among actors; but only firms with higher absorptive capacity levels are able fully to assimilate and exploit the absorbed knowledge for their innovations. Similarly, even if a firm is able to access unintended knowledge by monitoring other firms' innovative activities or using their patents, it still needs strong absorptive capacity to understand such knowledge for its own innovations and thus enhance its innovative performance. So we include absorptive capacity as a moderator effect in propositions 9 and 10.

Proposition 9: The relationship between intended knowledge flows and innovative performance of firms is positively moderated by higher levels of absorptive capacity.

Proposition 10: The relationship between unintended knowledge flows and innovative performance of firms is positively moderated by higher levels of absorptive capacity.

Our proposition can be summarised in a theoretical model that illustrates the main effects (see Figure 1) and moderating effects (see Figure 2). 


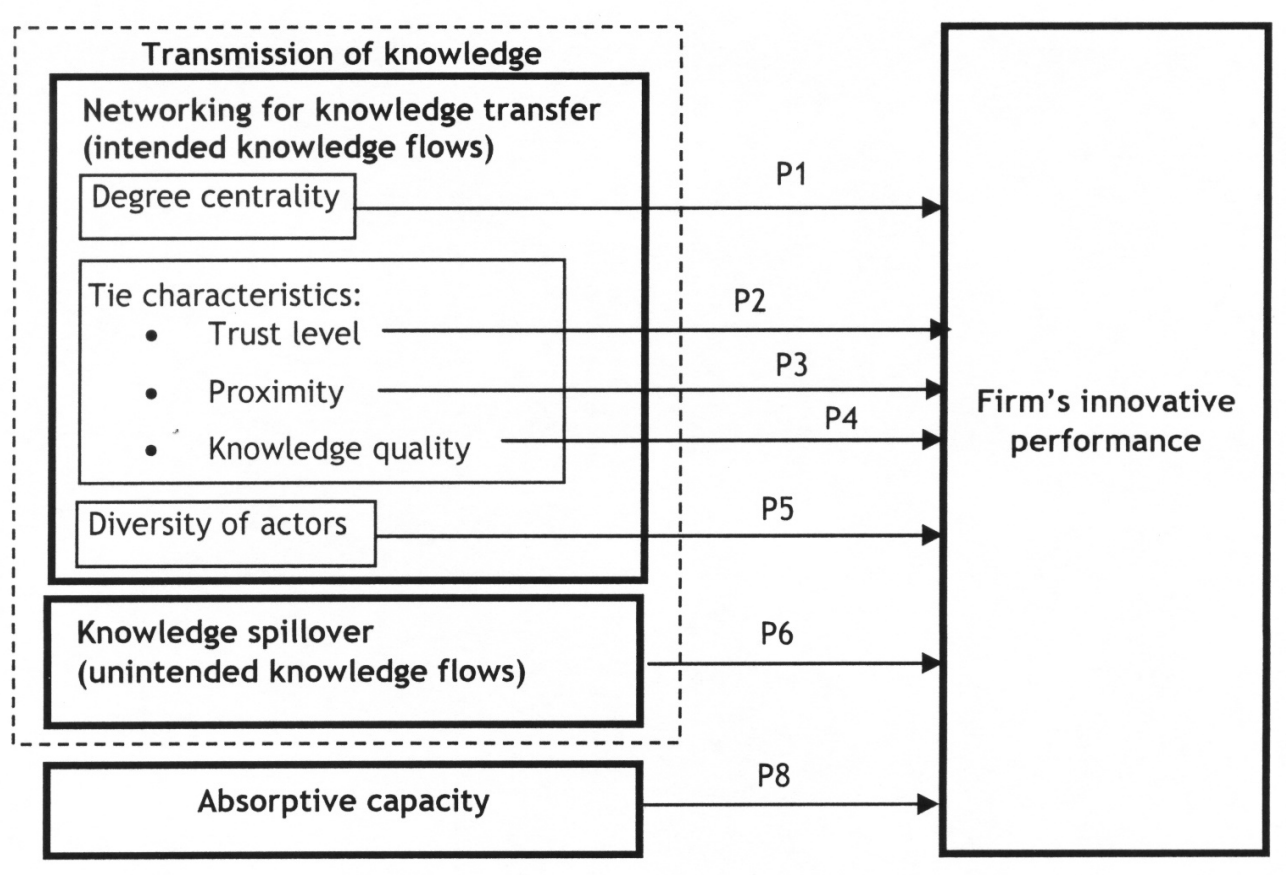

Figure 1: The theoretical model showing the main effects

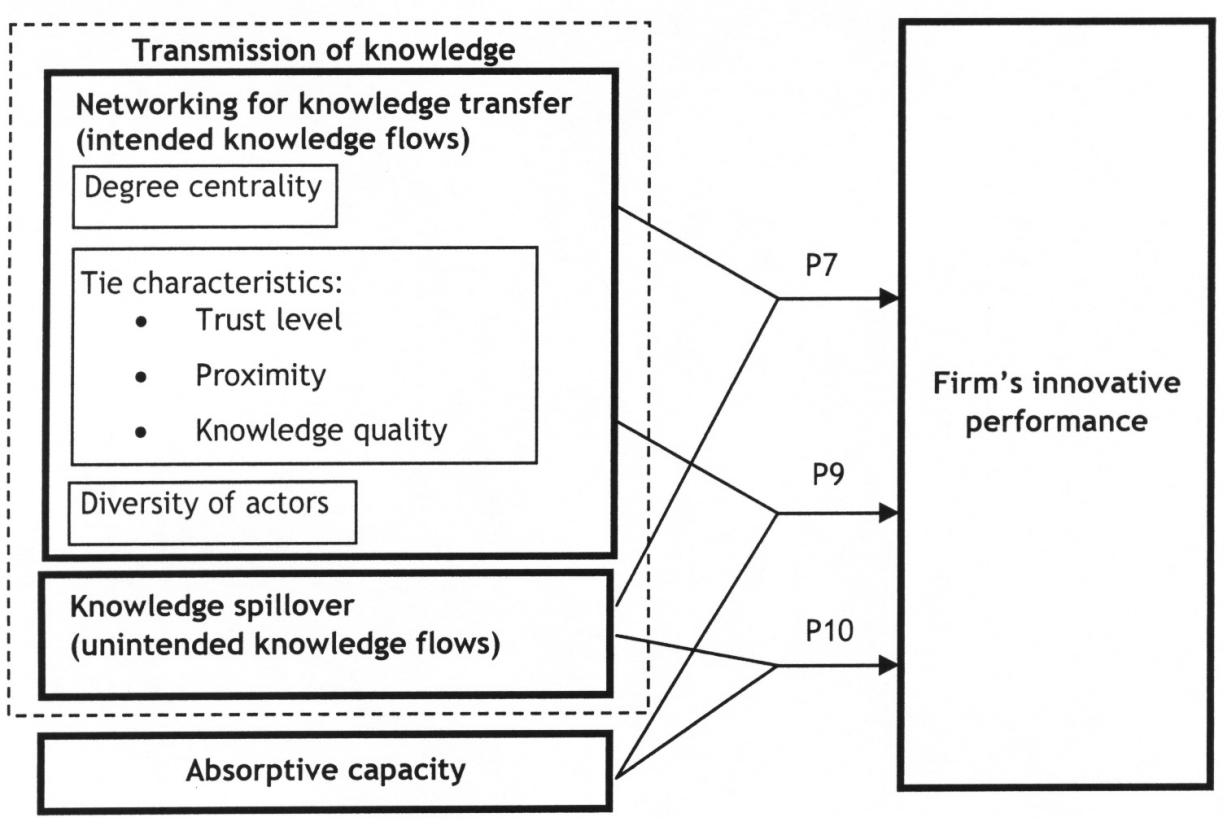

Figure 2: The theoretical model showing the interaction effects 


\section{CONCLUSIONS AND FUTURE RESEARCH}

This paper began with the observation that scholars find mixed empirical results on the performance of science park firms and science parks. The aim of this paper was to develop a theoretical argument to explain why these mixed results are found.

By using a deductive approach in which insights from inter-organisational network theory and the economics of innovation are combined, this paper proposes that interorganisational networks can have both positive and negative effects for firms located on science parks. One way to deal with the negative effects of unintended knowledge transfer is to (re)locate a firm further away from its partners with similar technological backgrounds or which are in similar industries [11]. However, firms located on science parks do not have a relocation option in the short run. Starting from this assumption, it is argued that the location of firms in related industries on science parks (thus creating high geographical and technological proximity) both can both foster and inhibit on-park knowledge flows and collaborations. The reason is that close geographical proximity enables on-park firms to monitor co-located firms' innovation activities, enhancing the possibility of imitation. Sender-firms can relatively easily identify which on-park firms imitate their innovations, resulting in less willingness to share knowledge in formal collaborations and/or informal networking activities with other on-park firms. As a result, the innovative performance of firms might suffer, leading to lower innovative performance as a whole in science parks.

In sum, the mixed empirical results found in the literature can be explained theoretically by pointing out that the very reasons why science parks are established - that is, to allow geographically co-located and technology-related firms intentionally to exchange knowledge through inter-organisational relationships and networks - at the same time create the conditions of unintentional knowledge transfer. If the latter occurs, interorganisational knowledge transfer between science park firms is severely inhibited, resulting in poor(er) science park performance.

From a managerial point of view, one could recommend that science park firms refrain from acting opportunistically. But that is stating the obvious. In our view, there is an important task here for the management of the science park. By creating a positive collaboration culture - for example, by stimulating social networking between entrepreneurs, by monitoring the behavior of tenants, or by training organisations in intellectual property protection - the propensity of firms to misuse others can be lowered.

So far, the proposed model has not been empirically validated. Results of future studies, coupled with previous findings and the model proposed here, will enhance our understanding of the interrelationships between inter-organisational knowledge transfer, absorptive capacity, science park location, and firms' innovative performance.

\section{REFERENCES}

[1] Bigliardi, B., Dormio, A. I., Nosella, A. \& Petroni, G. 2006. Assessing science parks' performances: Directions from selected Italian case studies, Technovation, 26(4), pp. 489-505.

[2] Goldstein, H. A. \& Luger, M. I. 1990. Science/technology parks and regional development theory, Economic Development Quarterly, 4(1), pp. 64-78.

[3] Goldstein, H. A. \& Luger, M. I. 1991. Technology in the garden: Research parks and regional economic development, University of North Carolina Press.

[4] Löfsten, H. \& Lindelöf, P. 2003. Determinants for an entrepreneurial milieu: Science parks and business policy in growing firms, Technovation, 23(1), pp. 51-64. 
[5] Westhead, P. \& Batstone, S. 1999. Perceived benefits of a managed science park location, Entrepreneurship \& Regional Development, 11(2), pp. 129 - 154.

[6] Ferguson, R. and Olofsson, C. 2004. Science parks and the development of NTBFs location, survival and growth, Journal of Technology Transfer, 29(1), pp. 5-17.

[7] Fukugawa, N. 2006. Science parks in Japan and their value-added contributions to new technology-based firms, International Journal of Industrial Organisation, 24(2), pp. 381-400.

[8] Chan, K.F. \& Lau, T. 2005. Assessing technology incubator programs in the science park: The good, the bad and the ugly, Technovation, 25(10), pp. 1215-1228.

[9] Quintas, P., D. W. \& Massey, D. 1992. Academic-industry links and innovation: Questioning the science park model, Technovation, 12(3), pp. 161-175.

[10] Westhead, P. 1997. R\&D 'inputs' and 'outputs' of technology-based firms located on and off science parks, R\&D Management, 27(1), pp. 45-62.

[11] Alcacer, J. \& Shao, M. 2007. Global competitors as next-door neighbors: Competition and geographic concentration in the semiconductor industry, Ross School of Business Paper No 1091.

[12] IASP website. Abour Science and Technology Parks. Definitions. http://www.iasp.ws, accessed 17/02/2009.

[13] Link, A.N. \& Link, K.R. 2003. On the growth of U.S. science parks, Journal of Technology Transfer, 28(1), pp. 81-85.

[14] Löfsten, H. \& Lindelöf, P. 2002. Growth, management and financing of new technology-based firms assessing value-added contributions of firms located on and off science parks, Omega, 30(3), pp. 143-154.

[15] Gordon, I. R \& McCann, P. 2000. Industrial clusters: Complexes, agglomeration and/or social networks? Urban Studies, 37(3), pp. 513-532.

[16] Romijn, H. \& Albu, M. 2002. Innovation, networking and proximity: Lessons from small high technology firms in the UK, Regional Studies, 36(1), pp. 81-86.

[17] Phillimore J. 1999. Beyond the linear view of innovation in science park evaluation: An analysis of Western Australian Technology Park, Technovation, 19(11), pp. 673680 .

[18] Monck, C.S.P., Porter, R.B., Quintas, P., Storey, D.J. \& Wynartcsyk, P. 1988. Science parks and the growth of high technology firms, Croom Helm.

[19] Westhead, P. \& Batstone, S. 1998. Independent technology-based firms: The perceived benefits of a science park location, Urban Studies, 35(12), pp. 2197-2219.

[20] Johannisson, B., Alexanderson, O., Nowicki K. \& Senneseth, K. 1994. Beyond anarchy and organisation: Entrepreneurs in contextual networks, Entrepreneurship and Regional Development, 6(4), pp. 329-356.

[21] Von Zedtwitz, M. \& Grimaldi, R. 2006. Are service profiles incubator-specific? Results from an Empirical Investigation in Italy, The Journal of Technology Transfer, 31(4), pp. 459-468. 
[22] Fallah, M. H. \& Ibrahim, S. 2004. Knowledge spillover and innovation in technological clusters, International Association for Management of Technology (IAMOT), Washington, DC.

[23] Oerlemans, L.A.G. \& Meeus, M.T.H. 2005. Do organizational and spatial proximity impact on firm performance?, Regional Studies, 39(1), pp. 89-104.

[24] Cross, R. \& Cummings, J.N. 2004. Ties and network correlates of individual performance in knowledge-intensive work, Academy of Management Journal, 47(6), pp. 928-937.

[25] Mowery, D.C., Oxley J.E. \& Silverman, B.S. 1996. Strategic alliance and interfirm knowledge transfer, Strategic Management Journal, 17 (Winter Special Issue), pp. 77-91.

[26] Arrow, K. 1962. Economic welfare and the allocation of resources for inventions, in The rate and direction of innovative activity, Nelson, R., Princeton University Press.

[27] Nelson, R. 1959. The simple economics of basic scientific research, Journal of Political Economy, 67(3), pp. 297-306.

[28] Cowan, R. \& Jonard, N. 2004. Network structure and the diffusion of knowledge, Journal of Economic Dynamics and Control, 28(8), pp. 1557-1575.

[29] Kingsley, G. \& Malecki, E. J. 2004. Networking for Competitiveness, Small business economics, 23(1), pp. 71-84.

[30] Pittaway, L., Robertson, M., Munir, K., Denyer, D. \& Neely, A. 2004. Networking and innovation: A systematic review of the evidence, International Journal of Management Reviews, 5-6 (3-4, pp. 137-168.

[31] Rothwell, R. 1992. Successful industrial innovation: Critical factors for the 1990s, R\&D Management, 22(3), pp. 221-240.

[32] Van de Ven, A.H. 1986. Central problems in the management of innovation, Management Science, 32(5), pp. 590-607.

[33] Bell, G.G. 2005. Clusters, networks, and firm innovativeness, Strategic Management Journal, 26(3), pp. 287-295.

[34] Powell, W. W., Koput, K. W., Smith-Doerr, L. \& Owen-Smith, J. 1999. Network position and firm performance, in Research in the Sociology of organizations, S. Andrews and D. Knoke, JAI Press.

[35] Saheer A.\& Bell, G.G. 2005. Benefiting from network position: Firm capabilities, structural holes, and performance, Strategic Management Journal, 26(9), pp. 809825.

[36] Ahuja, G. 2000. Collaboration networks, structural holes, and innovation: A longitudinal study, Administrative Science Quarterly, 45(3), pp. 425-455.

[37] Chang, Y.C. 2003. Benefits of co-operation on innovative performance: Evidence from integrated circuits and biotechnology firms in the UK and Taiwan, R\&D Management, 33(4), pp. 425-437.

[38] Cheuk, B. 2007. Social networking analysis: Its application to facilitate knowledge transfer, Business Information Review, 24(3), pp. 170-176. 
[39] Sparrowe, R.T., Liden, R.C., Wayne, S.J. \& Kraimer, M.L. 2001. Social networks and the performance of individuals and groups, Academy of Management Journal, 44(2), pp. 316-326.

[40] Granovetter, M. 1983. The strength of weak ties: A network theory revisited, Sociological Theory, 1, pp. 201-233.

[41] Newell, S. \& Swan, J. 2000. Trust and inter-organizational networking, Human Relations, 53(10), pp. 1287-1328.

[42] Lin, S. 2002. The dynamics of inter-organizational ties during crises: Empirical evidence and computational analysis, Simulation Modelling Practice and Theory, 10(5-7), pp. 387-415.

[43] Cross, R. \& Sproull, L. 2004. More than an answer: Information relationships for actionable knowledge, Organisation Science, 15(4), pp. 446-462.

[44] Hansen, M. T. 1999. The search-transfer problem: The role of weak ties in sharing knowledge across organisation subunits, Administrative Science Quarterly, 44(1), pp. $82-111$.

[45] Storper, M. 1997. The regional world: Territorial development in a global economy, London: Guildford Press.

[46] Lorens, E. 1999. Trust, contract and economic competition, Cambridge Journal of Economics, 23(3), pp. 301-315.

[47] Lasaric, N. \& Lorens, E. 1998. The learning dynamics of trust, reputation and confidence, in Trust and economic learning, N. Lasaric \& Lorens, E., Edward Elgar.

[48] Gertler, M. S. 1995. Being there: Proximity, organization, and culture in the development and adoption of advanced manufacturing technologies, Economic Geography, 71(1), pp pp. 1-26.

[49] Knoben, J. \& Oerlemans, L.A.G. 2008. Ties that spatially bind? A relational account of the causes of spatial firm mobility, Regional Studies, 42(3), pp. 385-400.

[50] Orlando, M.J. 2000. On the importance of geographic and technological proximity for R\&D spillovers: An empirical investigation, Federal Reserve Bank of Kansas City Research, Working Paper No 00-02.

[51] Boschma, R. 2005. Proximity and innovation: A critical assessment, Regional Studies, 39(1), pp. 61-74.

[52] Cassiman, B., Colombo, M. G., Garrone, P. \& de Veugelers, R. 2005. The impact of M\&A on the R\&D process: An empirical analysis of the role of technological- and market-relatedness, Research Policy, 34(2), pp. 195-220.

[53] Lane, P.J. \& Lubatkin, M.H. 1998. Relative absorptive capacity and interorganisational learning, Strategic Management Journal, 19(5), pp. 461-477.

[54] Rallet, A. \& Torre, A. 1999. Is geographical proximity necessary in the innovation networks in the era of global economy?, GeoJournal, 49(4), pp. 373-380.

[55] Soo, C.W. \& Devinney, T.M. 2003. The role of knowledge quality in firm performance, in Organizations as knowledge systems: Knowledge, learning and dynamic capabilities, H. Tsoukas \& N. Mylonopoulos London: Palgrave. 
[56] Reagans, R. \& McEvily, B. 2003. Network structure and knowledge transfer: The effects of cohesion and range, Administrative Science Quarterly, 48(2), pp. 240-267, 2003.

[57] Audretsch, D.B. \& Feldman, M.P. 2004. Knowledge spillovers and the geography of innovation, in Handbook of Urban and Regional Economics, Henderson J.V. \& Thisse, J.F., North Holland.

[58] Gulati, R. \& Gargiulo, M. 1999. Where do inter-organizational networks come from?, American Journal of Sociology, 104(4), pp. 1439-1493.

[59] Staber, U. 2001. The structure of networks in industrial districts, International Journal of Urban and Regional Resesarch, 25(3), pp. 538-552.

[60] Ussi, B. 1999. Embeddedness in the making of financial capital: How social relations and networks benefit firms seeking financing, American Sociological Review, 64(4), pp. 481-505.

[61] Cohendet, P. \& Llerena, P. 1997. Learning, technical change and public policy: How to create and exploit diversity, in Systems of innovation: Technologies, institutions and organisations, Cassel Pinter.

[62] Howells, J. R. L. 2002. Tacit knowledge, innovation and economic geography, Urban Studies, 39(5), pp. 871 - 884.

[63] Ulrich, K. 2000. Measuring knowledge spillovers in manufacturing and services: An empirical assessment of alternative approaches, Research Policy, 31(1), pp. 125-144.

[64] Jaffe, A.B., Henderson, R. \& Trajtenberg, M. 1993. Geographic localisation of knowledge spillovers as evidenced by patent citations, Quarterly Journal of Economics, 108(3), pp. 577-598.

[65] Cohen, W. \& Levinthal, D. 1990. Absorptive capacity: A new perspective on learning and innovation, Administrative Science Quarterly, 35(1), pp. 128-152.

[66] Sahra, S. A. \& George, G. 2002. Absorptive capacity: A review, reconceptualization, and extension, Academy of Management Review, 27(2), pp. 185-203.

[67] Pennings, J.M. \& Harianto, F. 1992. The diffusion of technological innovation in the commercial banking industry, Strategic Management Journal, 13(1), pp. 29-46.

[68] Becker, W. \& Peters, J. 2000. Technological opportunities, absorptive capacities, and innovation, Volkswirtschaftliche Diskussionsreihe.

[69] Nelson, R. \& Wolff, E.N. 1997. Factors behind cross-industry differences in technological progress, Structural Change and Economic Dynamics, 8(2), pp. 205-220. 